\title{
Experiência de geodiversidade do turista no Parque Nacional do Iguaçu (Paraná, Brasil)
}

\section{Resumo}

\author{
Raquel Virginia Rapanellia \\ José Elmar Feger \\ Luiz Alberto Fernandes ${ }^{c}$
}

A pesquisa investigou se a geodiversidade faz parte da experiência do turista, na trilha das Cataratas do Parque Nacional do Iguaçu no Brasil. 0 turista foi a unidade de análise. Na coleta das informações em campo foi usado o método Shadowing, com abordagem qualitativa. A elas somaram-se levantamento documental e bibliográfico, que foram tratadas pelo método de Análise de Conteúdo e interpretadas com base no aporte conceitual do turismo e domínios da experiência do modelo pine-gilmoriano, da geodiversidade e do geoturismo. A pesquisa foi realizada em área de visitação do Parque Nacional do Iguaçu, na trilha das Cataratas. Este é o trajeto onde o turista tem melhor visão das cataratas e é a única atividade já incluída no ingresso do parque. 0 estudo concluiu que os turistas não identificam espontaneamente o que veem como geodiversidade. Ou seja, não percebem os processos naturais - incluindo os geológicos, hidrológicos e geomorfológicos -, necessários para a formação daquela paisagem que os atrai, ou ainda, a percepção dos elementos abióticos explícitos envolvidos, tais como rochas e revelo. Os termos mencionados pelos turistas sobre esses elementos são os componentes da paisagem que lhes é mostrada.

Palavras-Chave: Geoturismo; Experiência turística; Paisagem natural; Unidade de conservação; Educação ambiental.

\section{Abstract \\ Tourist geodiversity experience in Parque Nacional do Iguaçu (Paraná, Brazil)}

This study investigated whether geodiversity is part of the tourist experience, on the Cataratas trail of the Iguaçu National Park in Brazil. The tourist was the analysis unit. The Shadowing method, with a qualitative approach, was used in the field information collection. To that was added a documental and bibliographic survey, which was then treated by using Content Analysis and interpreted based on the conceptual contribution of Tourism and Domains of Experience of the pine-gilmorian model, of Geodiversity and Geotourism. The research was carried out in a visitation area of the Parque Nacional do Iguaçu, on the Cataratas trail. This is the path in which the tourist has a better view of the falls and is the only activity already included in the park ticket. The study concluded that tourists do not spontaneously identify the geodiversity. That is, they do not understand the natural processes - including geological, hydrological, and geomorphological processes - necessary for the formation of that

a. Mestra em Turismo pela Universidade Federal do Paraná (UFPR). Curitiba, Paraná, Brasil. E-mail: raquelrapanelli@gmail.com.

b. Doutor em Desenvolvimento Regional pela Universidade de Santa Cruz do Sul (UNISC). Docente do Programa de pós-graduação em Turismo pela Universidade do Paraná (UFPR), Curitiba, Paraná, Brasil. E-mail: elmar.josefeger@gmail.com.

c. Doutor em Ciências/Geologia Sedimentar pelo Instituto de Geociências da Universidade de São Paulo (USP). Docente no Programa de pós-graduação em Geologia da Universidade Federal do Paraná (UFPR), Curitiba, Paraná, Brasil. E-mail: lufernandes@ufpr.br. 
landscape that attracts them, or even the perception of the explicit abiotic elements involved, such as rocks and relief. The terms mentioned by tourists about these elements are the components of the landscape shown to them.

Keywords: Geotourism; Touristic experience; Natural landscape; Conservation unit; Environmental education.

\section{Resumen}

\section{Experiencia de geodiversidad del turista en el Parque Nacional Iguaçu (Paraná, Brasil)}

Esta investigación analizó si la geodiversidad es parte de la experiencia del turista, en el sendero de las Cataratas del Parque Nacional Iguazú, en el lado brasileño. El turista fue la unidad de análisis. En la recolección de datos en campo se utilizó el método Shadowing, con enfoque cualitativo. A ellos se sumó el relevamiento documental y bibliográfico, que luego fueron tratados mediante el Análisis de Contenido e interpretados a partir del aporte conceptual de Turismo y Dominios de Experiencia del modelo pine-gilmoriano, de la Geodiversidad y el Geoturismo. Esta investigación se llevó a cabo en un área de visita del Parque Nacional do Iguaçu, en el sendero de las Cataratas. Este es el camino donde el turista tiene una mejor vista de las Cataratas y es la única actividad incluida en las entradas al parque. Se concluyó que los turistas no identifican espontáneamente la geodiversidad que están viendo. Es decir, no comprenden los procesos naturales, que incluyen procesos geológicos, hidrológicos y geomorfológicos, necesarios para la formación de ese paisaje que los encanta, ni siquiera perciben los elementos abióticos explícitos involucrados, como las rocas y el relieve. Los términos mencionados por los turistas sobre estos elementos son los que componen el paisaje que se les presenta.

Palabras clave: Geoturismo; Experiencia turística; Paisaje natural; Unidad de conservación; Educación ambiental.

\section{INTRODUÇÃo}

Estudos apontam (e.g. Houshold \& Sharples, 2008; Gray, 2013) que o conceito de geodiversidade surgiu em discussões do Serviço Florestal da Tasmânia na Austrália, em meados de 1980. Por necessidade de identificar e nomear a diversidade dos elementos que compõem espaços de natureza abiótica para justificar sua conservação.

A demanda pela geoconservação uniu geólogos e geomorfólogos a partir da década de 90 principalmente na Austrália e Europa, e hoje está bastante difundida no mundo. Dentro desse campo conceitual da geoconservação serão tratados nesta pesquisa o conceito de geodiversidade, que após o evento Rio92 se afirmou como contraposição e complemento à biodiversidade (Serrano \& Ruiz, 2007), e o conceito de geoturismo.

A geodiversidade é a variedade natural de elementos geológicos (rochas, minerais, fósseis), elementos geomorfológicos (relevo, topografia, processos físicos), solos e elementos hidrológicos, incluindo suas composições, associações, estruturas, sistemas, e contribuições para a formação da paisagem de acordo com Gray (2013, p. 12). É o suporte para a vida na Terra (Brilha, 2005), dessa forma, pode-se admitir que os elementos da geodiversidade formem a paisagem natural e representem sua camada física (Gray, 2013). 
As paisagens são elementos essenciais ao fenômeno turístico (Pires, 2011). Paisagens naturais como as das Cataratas do Iguaçu são exemplos de geodiversidade e de atrativo turístico, porque provocam afluência de turistas (Beni, 2002). Desse encontro pode acontecer o geoturismo que é, de acordo com Hose (2012), o fornecimento de instrumentos interpretativos para geossítios, geomorfossítios e sua topografia, visando à conservação por meio da apreciação, aprendizagem e pesquisa.

O geoturismo propõe uma experiência mais profunda do turista com a paisagem.

Experiências ricas são aquelas mais completas, atingem o sujeito emocional, física, espiritual e intelectualmente (Cutler \& Carmichael, 2010; Pine II \& Gilmore, 2011).

Desde a década de 60, pesquisadores têm estudado os detalhes da experiência turística (Jennings et al., 2006) e no final da década de 90, B. Joseph Pine II e James H. Gilmore $(1998 ; 1999)$ apresentaram resultados de estudo notadamente com aporte do Marketing, sobre consumo experiencial, no qual defendem que bens e serviços já não são suficientes, e para que se avance na produção econômica, devem ser oferecidas experiências. Criaram um modelo de análise dessa experiência individual, aqui designado pine-gilmoriano (Pine II \& Gilmore, 1999). Ele tem sido utilizado e revisado por estudiosos do turismo, como se pode verificar em Oh, Fiore e Jeoung (2007), Mehmet Mehmetoglu e Marit Engen (2011), Gândara, Fraiz Brea e Manosso (2013), Marujo (2016), Pezzi e Vianna (2015), Bezerra (2019), Conti, Forlani e Pencarelli (2020), entre outros. Esta abordagem considera que experiências são eventos que envolvem o indivíduo de forma pessoal (Pine II \& Gilmore, 1999), quando surge uma relação entre sujeito e objeto (Mehmetoglu e Marit Engen, 2011).

Foi com este ambiente conceitual que a investigação ora apresentada buscou saber se o turista, como sujeito da ação do turismo, que vai ao Parque Nacional do Iguaçu (PARNA Iguaçu) visitar a trilha das Cataratas tem a geodiversidade como elemento de referência, em sua experiência turística, percebendo os elementos abióticos da paisagem que o motiva a estar lá, e, portanto praticando o geoturismo.

\section{Área de estudo}

Num profundo clamor,

Salta no abismo o turbilhão das águas,

Referve na garganta, em convulsões, e espuma,

Ergue-se em renda e névoa, que o sol irisa.

No imenso palco escarpado,

Esgarçam-se líquidos tules,

Há esguias águas dançantes,

Nevoeiros de arco-íris.

No abismo do tempo imemorável,

Reboa, soturna, a voz das cataratas. (Kolody, 1995, p. 160) 
O PARNA Iguaçu, que existe desde 1939 como Unidade de Conservação (UC) protege a Mata Atlântica e a paisagem singular das Cataratas (ICMBio, 2018). Em conjunto com o Parque Nacional Iguazú, na Argentina foi escolhido em 1986 como Sítio do Patrimônio Mundial Natural no Brasil pela Organização das Nações Unidas (Unesco, 2020). No final dos anos 90, o Serviço Geológico do Brasil (CPRM) criou a Comissão Brasileira de Sítios Geológicos e Paleobiológicos (SIGEP) com objetivo de realizar um inventário e fomentar ações conservacionistas. O PARNA Iguaçu e as Cataratas foram catalogados como sítio geomorfológico brasileiro número 11 (Salamuni et al., 2002).

No ano de 2017, em que se desenvolveu a presente pesquisa (Rapanelli, 2018), houve 1.788 .922 de visitantes, o maior número registrado desde 1953 (Trevisan, 2020), crescente até a interrupção das atividades devido ao isolamento social imposto pela pandemia de COVID19, em 2020.

Como categoria de Parque Nacional, a UC deve desenvolver ações de preservação de ecossistemas naturais de grande relevância ecológica e beleza cênica, realizar pesquisas científicas e desenvolver atividades de educação e interpretação ambiental, de recreação em contato com a natureza e de turismo ecológico (Brasil, 2011). A entrada do parque está no município de Foz do Iguaçu (figura 1), cidade situada a $630 \mathrm{~km}$ de Curitiba, capital do estado do Paraná.

Figura 1 - Área de estudos
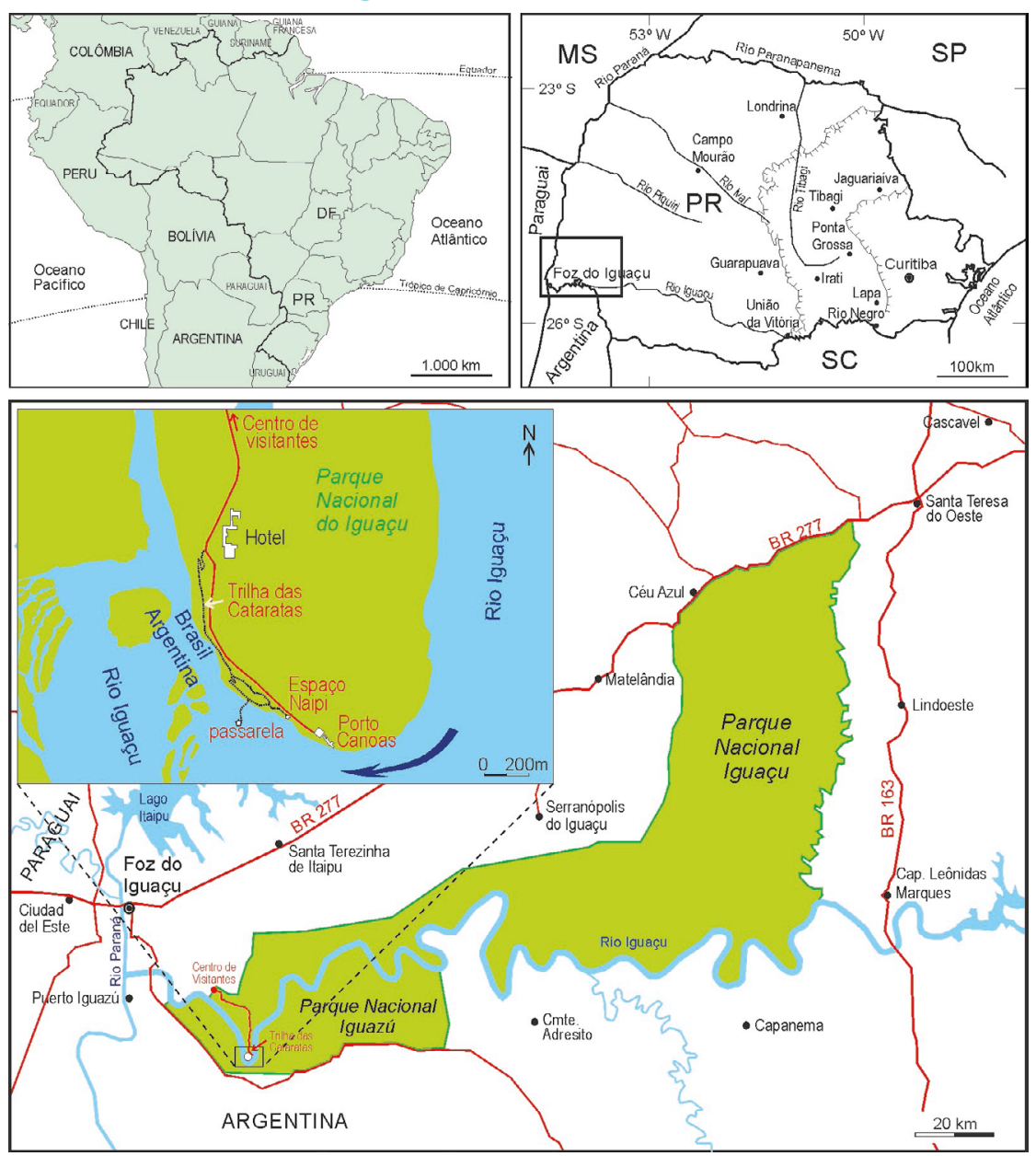

Nota: localização do estado do Paraná, com destaque para a trilha das Cataratas.

Fonte: autores. 
A partir da trilha das Cataratas, com seus mirantes (figura 2 e 3), se tem a melhor visão dos "mais belos e famosos saltos do mundo" como afirmou Reinhard Maack (1968, p. 282), geólogo e naturalista alemão, pesquisador do território paranaense.

Figura 2 - Trilha das Cataratas

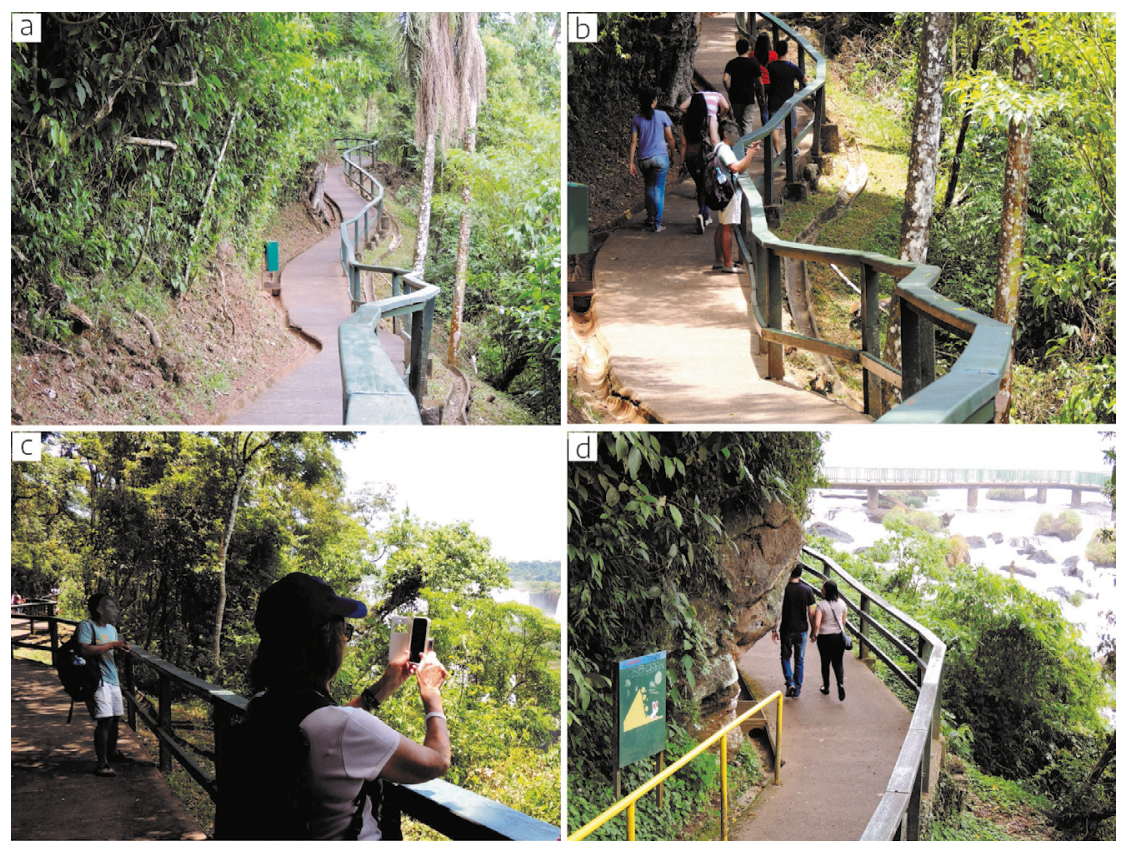

Nota: $(\mathrm{a}, \mathrm{b}, \mathrm{c})$ a trilha acompanha o curso do rio por $1.200 \mathrm{~m}$ de extensão, em meio à mata ao som intenso e incessante das quedas d'água; (d) trecho final da trilha, passarela ao fundo. Fotos de 2017, autores.

\section{Figura 3 - Mirantes}

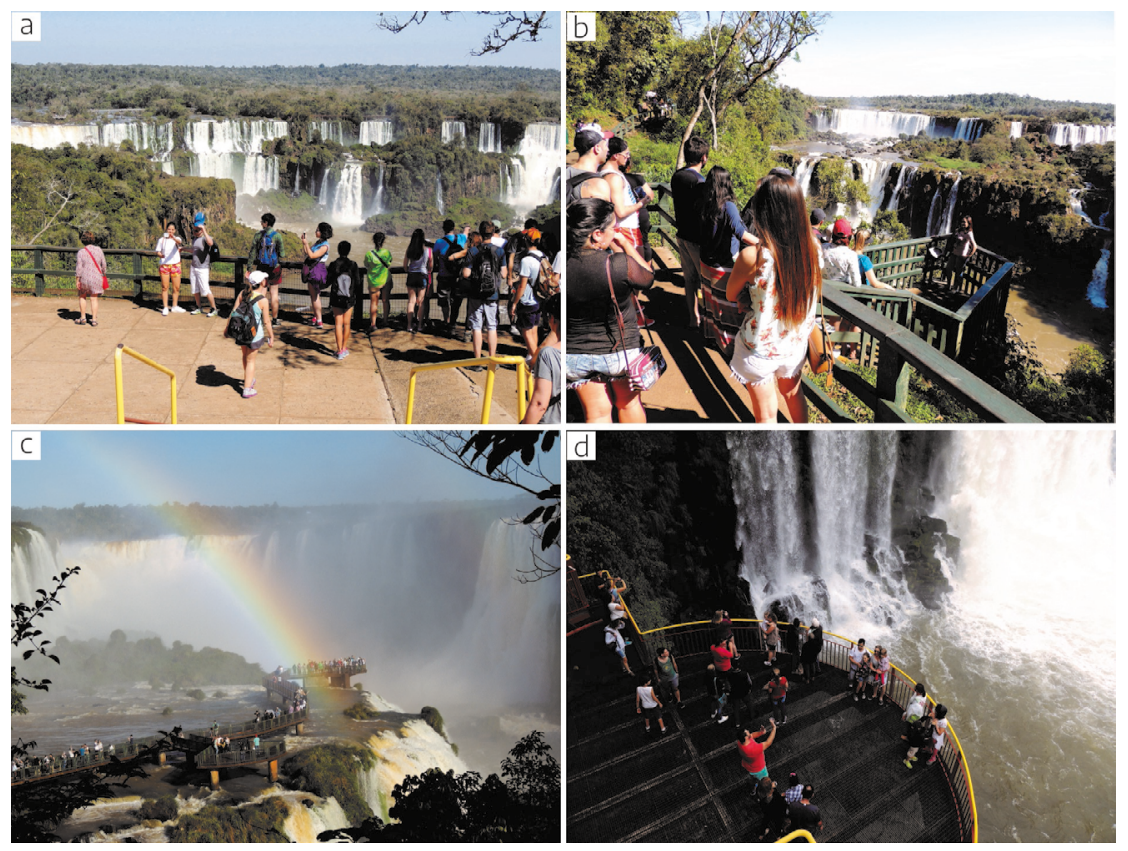

Nota: (a) início da trilha; (b) um dos locais concorridos do percurso; (c) passarela da Garganta do Diabo; (d) último da trilha, antes do elevador panorâmico, bastante próximo à queda d'água. Fotos de 2017, autores. 
A paisagem que o turista busca na trilha das Cataratas é composta por elementos da geodiversidade e da biodiversidade. Os processos fluviais, clima, solos, rochas, desníveis do terreno e cobertura vegetal estão inter-relacionados e são agentes modeladores dessa paisagem singular (IBAMA, 2002).

\section{Geodiversidade das Cataratas}

O PARNA Iguaçu situa-se sobre basaltos da Formação Serra Geral, que integram o conjunto de rochas que constituem o preenchimento a Bacia Sedimentar do Paraná.

As rochas basálticas formaram-se da consolidação em superfície de lavas não explosivas oriundas do interior do planeta (magmas) há cerca de 130 milhões de anos atrás, no período Cretáceo Inferior (145 a 99 Ma) da era Mesozóico. 0 magma extravasou por meio de grandes fendas da crosta terrestre geradas na ruptura do supercontinente Gondwana, que existiu durante a era Paleozóico (359 a 250 Ma). Dessa ruptura também decorreu a separação das placas Sul-americana e Africana, e a formação do oceano Atlântico. Esses derrames ocorreram em escala continental.

Na área do PARNA Iguaçu, os derrames basálticos formam estratos tabulares (figuras 4, 5a), sobrepostos, com espessura total entre 750 e $800 \mathrm{~m}$ (Salamuni et al., 2002). Algumas de suas características típicas são: horizontes com vesículas - vazios esféricos ou alongados -, e amígdalas - vesículas preenchidas por minerais (figuras 4, 6a, b); empilhamento de camadas tabulares bem definidas, correspondentes aos derrames (figuras 4, 5a, 6c, d), e sistemas de fraturas paralelas (figuras $4,5 b, c)$.

Figura 4 - Os derrames

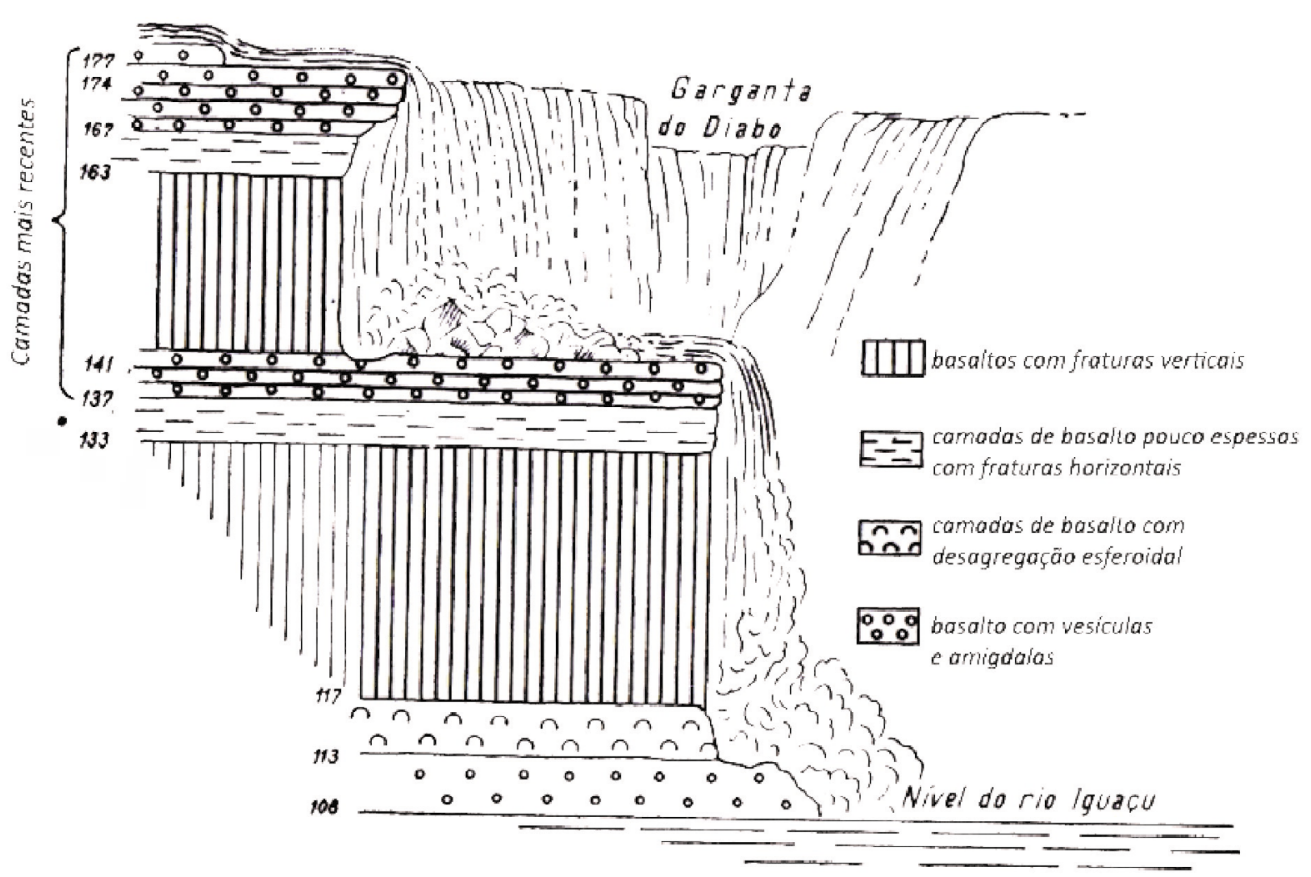

Fonte: autores, ilustração modificada de Maack (1968).

0 relevo regional apresenta topos de cotas entre 100 e $300 \mathrm{~m}$, formado por colinas suavemente onduladas, com predominância de perfis de topos 
planos. A paisagem tabuliforme é comum em terrenos de derrames basálticos, e bastante influenciada pelos processos climáticos atuais de modelagem de relevo (Salamuni et al., 2002).

O rio Iguaçu tem a maior bacia hidrográfica do Paraná. O Parque localiza-se na bacia do Baixo Iguaçu (ICMBio, 2018). Nesta área o rio Iguaçu forma cânion e pequenas praias arenossiltosas a jusante das quedas, entre as altitudes de 205 e $90 \mathrm{~m}$. 0 padrão de drenagem, de maneira geral, é retangular a sub-retangular, até subdendrítica nos detalhes. 0 rio Iguaçu é um dos principais agentes modeladores da paisagem da região (Maack, 1968; Salamuni et al., 2002). As principais classes de solos desenvolvidos nos basaltos são o latosolo roxo, terra roxa e solos gley (Salamuni et al., 2002).

A feição geomorfológica mais conhecida é denominada Cataratas do Iguaçu, constituída por um conjunto de cerca de 270 quedas (Maack, 1968), que totalizam desnível de $115 \mathrm{~m}$, segundo Salamuni et al. (2002). Em períodos de grande vazão do rio aparentam ser apenas uma grande queda. 0 maior salto, com $90 \mathrm{~m}$ de altura, é chamado de Garganta do Diabo (Maack, 1968).

As quedas d'água e cânion são produtos da ação de processos climáticos do período Quaternário (2.588 Ma - até o presente) e do intemperismo químico decorrente da cobertura vegetal de remanescentes do bioma Mata Atlântica. (Salamuni et al., 2002; ICMBio, 2018).

As figuras 5 e 6 apresentam os principais elementos da geodiversidade observáveis da trilha das Cataratas.

Figura 5 - Exemplos da geodiversidade das Cataratas

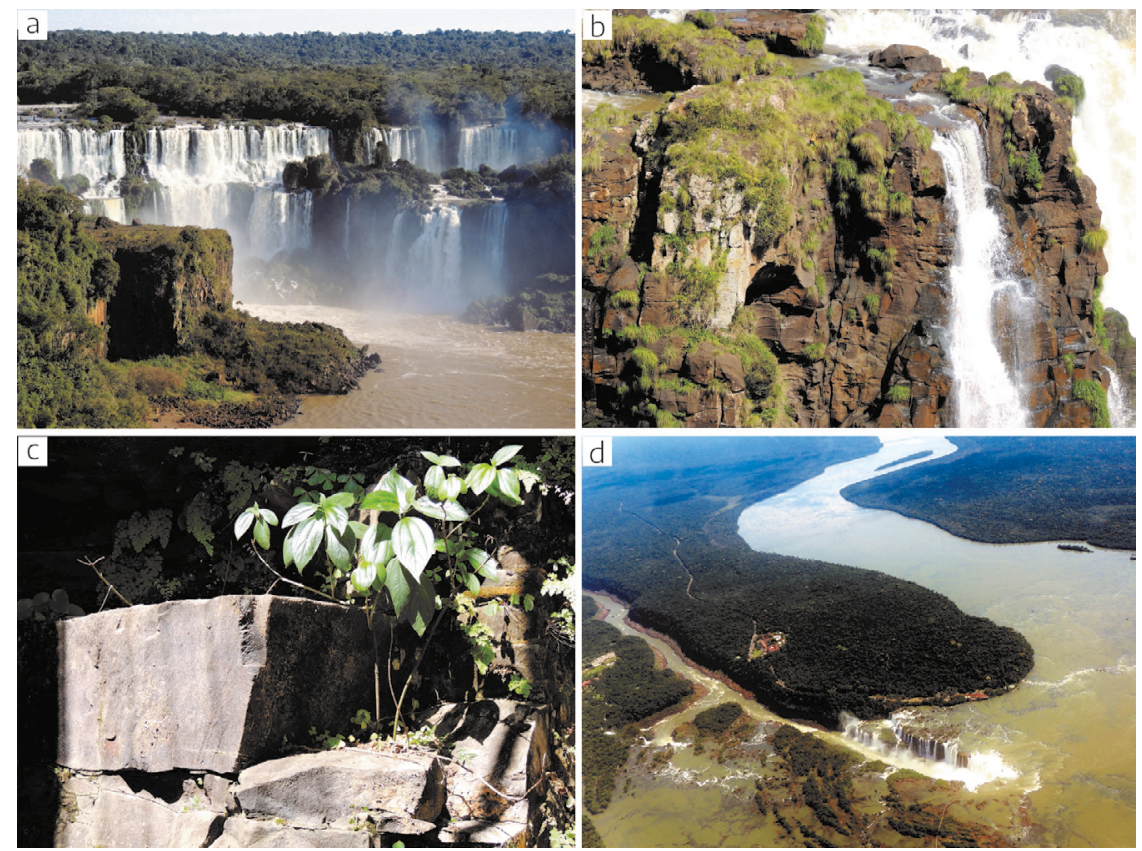

Notas: (a) feição geomorfológica das Cataratas, aspecto tabuliforme, comum em áreas de derrames basálticos; $(\mathrm{b}, \mathrm{c}$ ) cor escura característica de basaltos, devida à presença de cinzas vulcânicas e óxidos de ferro em sua composição; fraturas e articulações verticais que definem o entablamento, fraturas sub-horizontais, plano-paralelas devido ao movimento diferencial entre uma porção superior altamente viscosa já resfriada e o núcleo ainda líquido (Licht \&

Arioli, 2020); (d) foto aérea - o rio Iguaçu forma um semicírculo que pode chegar a

$2.700 \mathrm{~m}$ de largura acima das cataratas (Salamuni et al., 2002), estreitando-se até 65 a 100m na fenda tectônica (Maack, 1968). Fotos de 2017, autores. 
Figura 6 - Exemplos da geodiversidade das Cataratas.

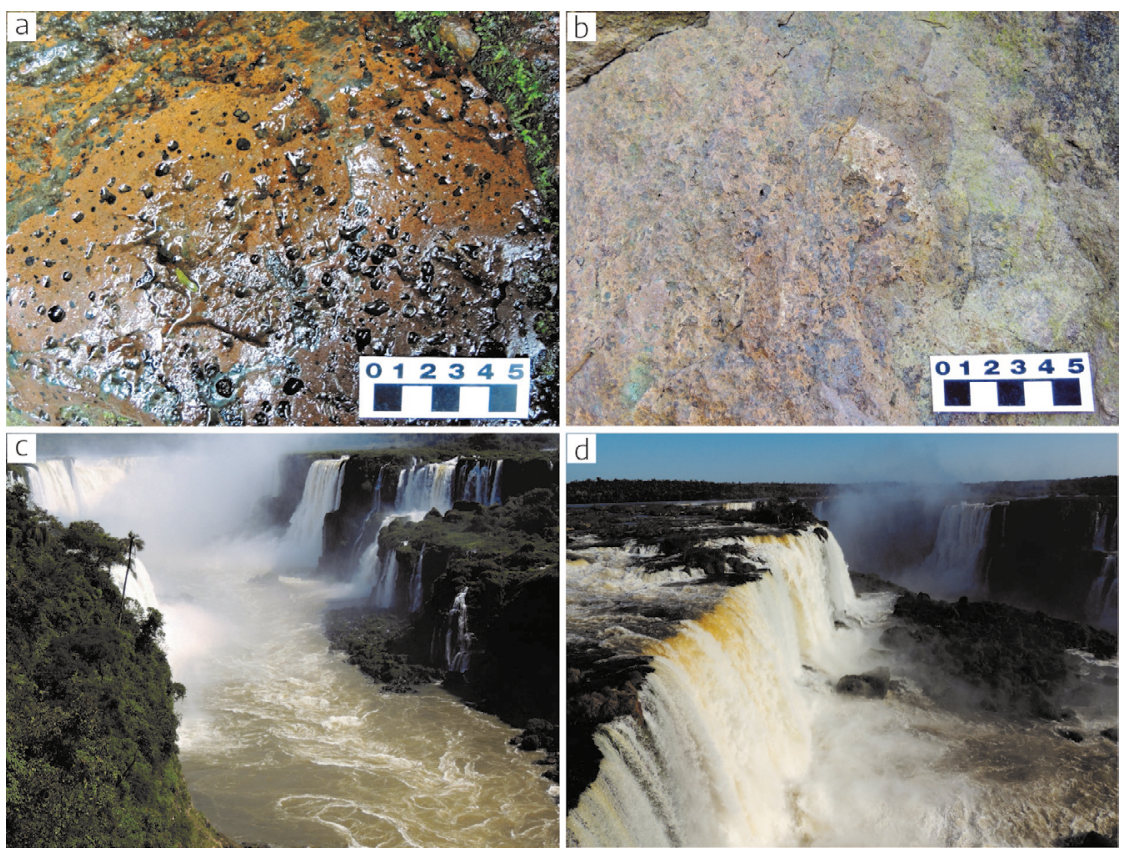

Notas: $(a, b)$ feições características de base e topo de derrames de basalto, formadas pelo resfriamento em superfície, de bolhas de líquidos e gases aprisionados no magma:

(a) amígdalas: quando preenchidas por minerais e (b) vesículas, quando vazias; (c,d) cânion formado pelo encaixe do rio Iguaçu na fenda tectônica; o estrangulamento no cânion gera vazão média de 1.800m³/s (Maack, 1968; Salamuni et al., 2002). Fotos de 2017, autores.

\section{Domínios da EXPeriência - Modelo Pine-gilmoriano}

Experiências turísticas são diferentes das experiências cotidianas (Cohen, 1979; Cutler \& Carmichael, 2010; Urry, 2001). Devem constituir um evento significativo para ser armazenado como memória (Larsen, 2007). Experiências acontecem com as pessoas nos destinos (Stamboulis \& Skayannis, 2003) e, portanto, alguns lugares constituir-se-ão como o foco principal da experiência (Marujo, 2016). Turistas experimentam diferentemente as mesmas situações (Pine II \& Gilmore, 1998, 1999, 2000, 2011). Podendo ser positivas ou negativas (Trigo, 2010) a depender de como o turista se relaciona com os acontecimentos. E assim, se tornará marcante, devido a um conjunto de variáveis (Bezerra 2019).

Larsen (2007) classificou a natureza interativa das experiências turísticas em três etapas: antes, durante, e após a viagem que, por sua vez, correspondem a três processos: expectativas, percepções e memórias. Na etapa antes da viagem, no planejamento os turistas antecipam possíveis eventos através de expectativas. Durante a viagem essas expectativas se transformam em percepções dos eventos. E após a viagem, em memórias.

O modelo pine-gilmoriano (1999), construído com base em pesquisas na área de psicologia, indicou que as pessoas se sentem mais felizes, e com maior sensação de bem estar, quando compram experiências, do que quando compram um bem (Boven \& Gilovich, 2003; Carter \& Gilovich, 2010). Essa constatação reforçou então o desenvolvimento de ofertas que valorizem seus produtos e serviços de 
forma a proporcionar experiências memoráveis e únicas aos seus consumidores (Oh, Fiore \& Jeoung, 2007). Assim, o modelo pine-gilmoriano desenha o consumo de experiências como fundamento para construir uma experiência memorável. Pezzi e Vianna (2015, p. 180) comprovaram que turistas diferenciam a experiência ordinária da extraordinária a partir desse mesmo modelo teórico.

A partir dos pontos de intersecção entre participação e conexão/envolvimento (figura 7) o resultado classifica a experiência individual em um domínio definido (Pine II \& Gilmore, 1999).

Figura 7 - Domínios da experiência modelo pine-gilmoriano

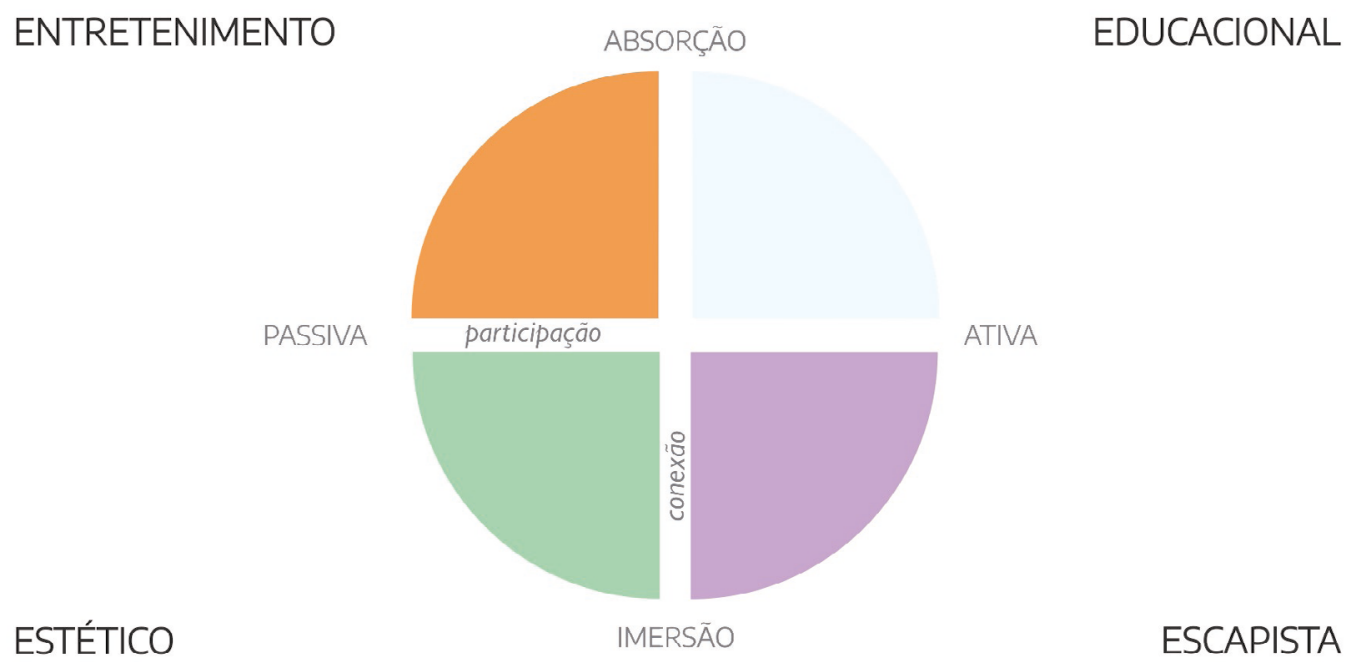

Fonte: autores, diagrama baseado em conceitos de Pine II e Gilmore (1998, 1999, 2011).

No eixo horizontal estão os dois polos que correspondem aos graus de participação: passiva ou ativa. Na participação passiva a pessoa é inerte, não atua no desempenho da experiência. Na participação ativa a pessoa atua a favor, criando sua própria experiência. No eixo vertical estão as dimensões que descrevem o tipo de conexão que une o indivíduo ao acontecimento da experiência. Em uma extremidade está a absorção, que envolve a atenção do indivíduo enquanto na outra extremidade está a imersão, que se ocupa fisicamente dele, como ver o jogo da arquibancada ou ser um jogador no campo, respectivamente (Pine II \& Gilmore, 1998). A união dessas quatro dimensões definiu os quatro domínios de experiência no modelo pine-gilmoriano, também chamado 4Es: entretenimento, educacional, escapista e estético, mutuamente compatíveis e quando misturados e somados criam experiências exclusivamente pessoais.

O domínio entretenimento é aquele que oferece diversão (Gândara; Fraiz Brea \& Manosso, 2013), o sujeito absorve passivamente a experiência através de seus sentidos, são experiências simples e ancestrais e por isso talvez as mais comuns.

O domínio educacional é de participação ativa porque necessita do total envolvimento do sujeito, intelectual ou fisicamente. Estimulam o desejo do aprendizado e aumentam os conhecimentos (Marujo, 2016; Oh; Fiore \& Jeoung, 2007).

O domínio do escapismo, ou de evasão, é o oposto polar do puro entretenimento (Pine II \& Gilmore, 2011, p. 49). Com esse domínio perde-se a noção de tempo (Gândara; Fraiz Brea \& Manosso, 2013). Na evasão "eu me diverti e me 
distrai" e no entretenimento, "me divertiram e me distraíram" (Gândara, 2018, julho). Portanto necessita de consciência do sujeito. Estar consciente implica reunir e estabelecer prioridades das sensações, percepções, sentimentos, entre todas as informações como em uma 'câmara de compensação'. Sem consciência haveria dependência apenas dos instintos e reflexos. Se a informação é importante na consciência, será a consciência que determinará o conteúdo da experiência (Csikszentmihalyi, 1990).

Finalmente, o domínio estético, ou de contemplação, o sujeito está passivamente imerso em uma realidade a qual ele não interfere, deixa essencialmente intacta (Pine II \& Gilmore, 1999). No domínio estético se ganha acuidade visual (Gândara; Fraiz Brea \& Manosso, 2013), aguça a percepção.

As experiências mais ricas, envolventes, convincentes, atraentes, serão aquelas que combinarão de forma criativa os quatro domínios, chamadas de experiência memorável (Pine II \& Gilmore, 1999).

\section{Procedimentos metodológicos}

A pesquisa teve como abrangência espacial exatamente a trilha das Cataratas, afinal ela propicia as condições necessárias: grande fluxo turístico, possibilidade de observação da geodiversidade local. A trilha também foi escolhida por ser a única incluída na compra do ingresso de acesso ao PARNA Iguaçu, o que a torna a representante do produto turístico. Neste sentido, ofereceu a oportunidade à pesquisadora de interagir diretamente com o turista que vai ao parque para conhecer as Cataratas.

Pesquisar na intangível experiência turística o conteúdo tangível e consciente da geodiversidade foi o desafio considerado nesta investigação. 0 desafio de buscar no turista a compreensão de que os elementos abióticos passam por processos para formar paisagens como a das Cataratas, que conforme Carcavilla (2012) e Gray (2013), entre outros especialistas mundiais, é um importante ícone de geodiversidade.

Pouco se tem pesquisado, a partir da perspectiva de quem viaja, para entender de que forma o turista se relaciona com essa paisagem de geodiversidade. A maior parte das investigações, principalmente ibero-latinoamericanas, que reúnem os temas de geodiversidade e turismo, foi produzida na área das Geociências e, focalizada principalmente na geodiversidade como potencial atrativo turístico, preterindo-se a análise da participação do turista (Rapanelli e Feger, 2018).

Esta, aqui apresentada, sobre o fenômeno do turismo e suas relações a partir da perspectiva do turista foi de abordagem qualitativa, que conforme Creswell (2010) explorou os significados que os indivíduos atribuem a um acontecimento social.

"Quando os turistas são questionados sobre suas férias, eles frequentemente se referem a experiências, e essas experiências são memórias que são criadas em um processo construtivo ou reconstrutivo no íntimo do indivíduo" (Larsen, 2007, p. 13). Por isso optou-se desenhar a coleta das informações em formato contínuo: antes, durante e após a visita. 0 método Shadowing permitiu o acompanhamento durante todo o percurso do turista na trilha. 
Esse "método móvel", Shadowing, tem sido usado em pesquisas nas ciências sociais com abordagens qualitativas (McDonald, 2005) por possibilitar a manutenção do ritmo aos eventos em tempo real por muitos espaços (McDonald \& Simpson, 2014). Para McDonald (2005) o método é o acompanhamento e observação do pesquisador ao pesquisado como uma sombra, quando tudo será observado, possibilitando registros do real instantâneo, da ação do sujeito no momento do contato com o objeto pesquisado. Esse sombreamento pode ser realizado por meses, dias ou turnos. Existe a possibilidade da interação entre o pesquisador e o pesquisado para melhor compreensão de algumas questões que possam surgir.

Com o Shadowing são obtidos mais detalhes justamente por não se basear em apenas um relato. As notas de campo são ao final analisadas como qualquer outro dado qualitativo, como fonte primária de informação. Não há um número exato de participantes para validar o método. Todavia esse tipo de coleta produz informações suficientes para uma análise segura (McDonald \& Simpson, 2014).

Valendo-se de critérios encontrados em outras discussões teóricas a respeito de número de participantes necessários para validação de pesquisas em que se atingiria a saturação, Minayo $(2017$, p. 6) afirmou "em resumo, uma quantidade consensual seria de, pelo menos, 20 a 30 entrevistas para qualquer tipo de investigação qualitativa".

O Shadowing foi composto por observação contínua de um determinado sujeito por um tempo acordado e também por entrevistas semiestruturadas com questões abertas, antes e depois do percurso da trilha.

A primeira abordagem ao participante foi feita na estação Centro de Visitantes. A partir do consentimento livre e esclarecido, a pesquisadora o entrevistou, embarcou junto no ônibus, descendo no ponto inicial da trilha das Cataratas (figura 8). O Shadowing foi iniciado imediatamente após o embarque e primeira parte da entrevista feita. 0 turista foi informado do acompanhamento e de que ao final da trilha seria novamente entrevistado.

Figura 8 - Croqui turístico do Parque Nacional Cataratas do Iguaçu

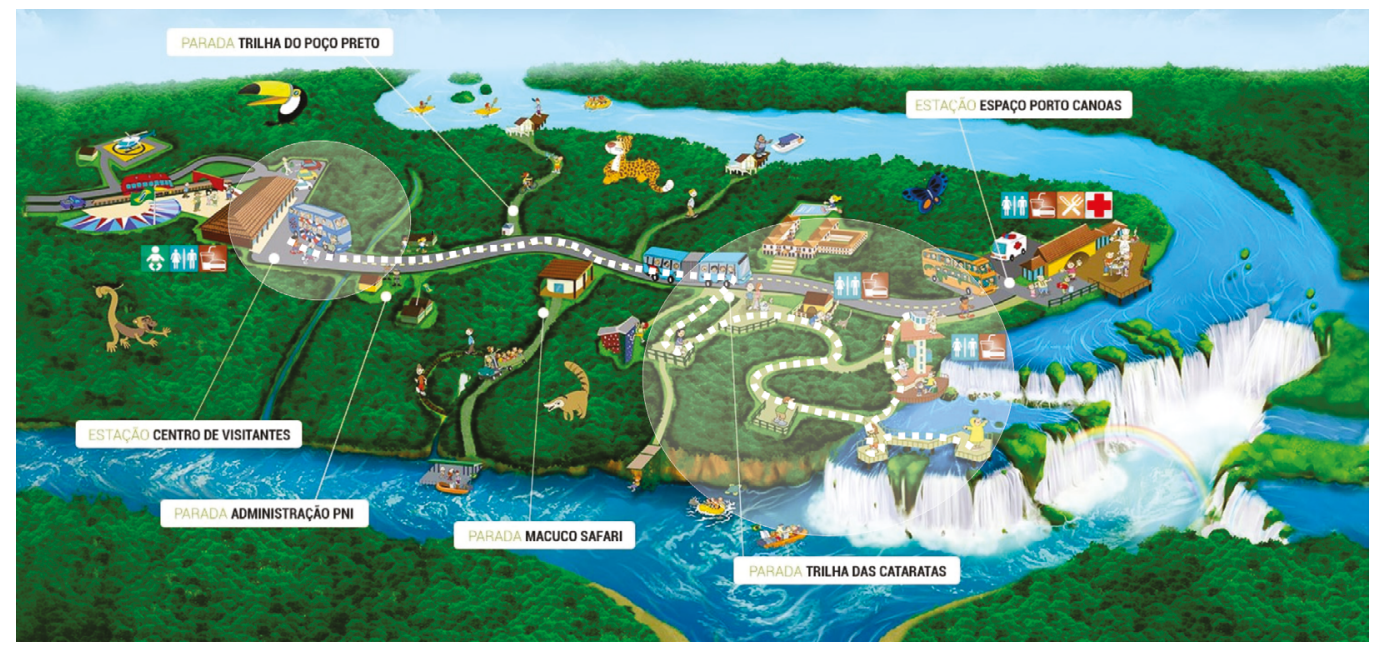

Nota: 0 círculo menor em branco indica onde ocorreu a primeira abordagem ao turista. A elipse maior mostra a trilha das Cataratas; no caminho tracejado a pesquisadora acompanhou o turista no Shadowing. Mapa modificado Cataratas do Iguaçu S. A. (2021), autores. 
Após o percurso pela trilha, e terminada a entrevista, deu-se por encerrada a participação do turista e a pesquisadora então revelou os detalhes da pesquisa: método, tema e explicações sobre a geodiversidade local.

A entrevista foi gravada em áudio com uso de celular, autorizada e à vista do participante. Ele teve ciência de que foi observado durante seu passeio, acompanhado pela pesquisadora, que também fez anotações. As coletas das informações do Shadowing (observação e entrevistas) seguiram roteiros pré-estruturados.

0 formato de roteiro empregado nesta pesquisa visou reduzir preconceitos e hipóteses preconcebidas da pesquisadora, segundo recomendam McDonald \& Simpson (2014). Por outro lado, McDonald (2005) alerta sobre o cuidado com a eventual mudança no comportamento do pesquisado pela consciência da observação. Por este motivo, optou-se por informar o turista "sombreado" somente ao final da última entrevista que a pesquisa era sobre a geodiversidade. A investigação também teve o cuidado de não impedir que o turista vivesse sua experiência turística, espontaneamente.

0 modelo pine-gilmoriano deu suporte à análise da experiência do turista e extração de suas percepções e impressões sobre a geodiversidade.

Para interpretar as informações com base na Análise de Conteúdo inicialmente escolheram-se as frases expressas durante a entrevista bem como as anotações do Shadowing como as unidades de registro. Foram consideradas como unidades de contexto o tempo em que a fala ou comportamento aconteceu: antes, durante ou após o percurso da trilha, chamadas de unidades de contexto temporal, classificadas em: motivação, atenção e lembrança.

Outra categorização foi feita para separar as características dominantes das unidades de registro e suas intenções: paisagem, infraestrutura e turismo.

Por fim, todos os termos referentes à geodiversidade encontrados nas unidades de registro (entrevista) foram assinalados.

Com todas as categorizações realizadas, as unidades de registro e de contexto foram organizadas em colunas, conformando a realidade dos acontecimentos passados. Em seguida foram classificadas de acordo com os domínios da experiência do modelo pine-gilmoriano.

\section{Unidade de Análise - o turista}

A pesquisa iniciou-se pela entrevista com o turista, escolhido aleatoriamente, na área de embarque no ônibus, meio de transporte oferecido pelo PARNA Iguaçu. Indivíduos sozinhos ou em grupo, com ou sem guia. Envolveu 24 participantes, em duas etapas. Cada Shadowing completo durou um tempo diferente, em média de duas horas. Os entrevistados foram moradores dos estados de São Paulo, Paraná, Minas Gerais, Paraíba, Alagoas, Ceará e Rio Grande do Sul; de idades entre 16 e 59 anos, sendo que na maioria dos casos era sua primeira visita ao PARNA Iguaçu. A figura 9 apresenta de modo sintético, os métodos usados na pesquisa. 
Figura 9 - Síntese dos métodos utilizados

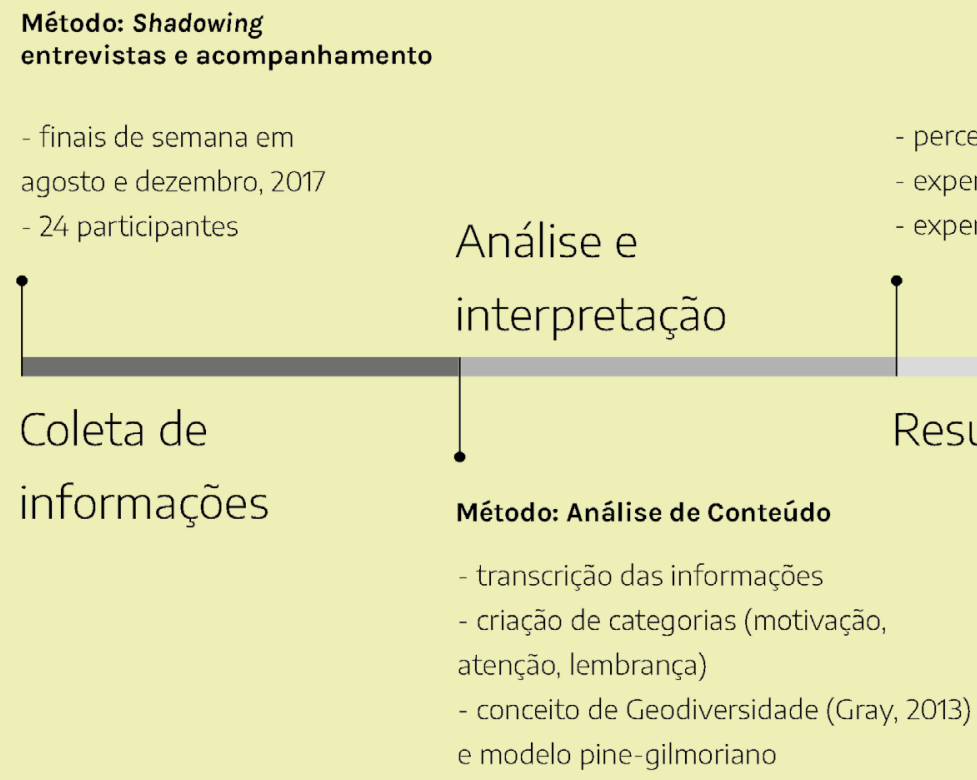

Fonte: autores.

\section{Resultados e discussões}

A análise dos resultados da pesquisa inicialmente mostrou a percepção do turista sobre a composição da paisagem, qual sua ideia de paisagem e capacidade de diferenciação entre elementos bióticos e abióticos. Comentários inteiros ou partes, de como os participantes ( $\left.\mathrm{Pn}^{\circ}\right)$ se expressaram sobre composição da paisagem em cada contexto temporal foram selecionados e apresentados no quadro 1.

Quadro 1 - Comentários sobre paisagem

\begin{tabular}{|c|c|c|}
\hline $\begin{array}{l}\text { contexto } \\
\text { temporal }\end{array}$ & $\begin{array}{l}\text { turista } \\
\text { participante }\end{array}$ & exemplo de comentário (unidade de registro) \\
\hline motivação & $\mathrm{P} 1$ & $\begin{array}{l}\text { "da paisagem, da natureza essa coisa que tem aqui sabe (...) é } \\
\text { a maior cachoeira do mundo (...) não é isso? É uma das maiores } \\
\text { cachoeiras do mundo. Vim porque gosto muito da natureza } \\
\text { (...) a natureza pra mim tem muita troca (...) essa relação com a } \\
\text { natureza, com a água, eu adoro" }\end{array}$ \\
\hline motivação & P15 & $\begin{array}{l}\text { "espero ver o que a gente vê na televisão, as cataratas, } \\
\text { as cachoeiras, a paisagem, o lugar (...) gosto bastante da } \\
\text { natureza" }\end{array}$ \\
\hline atenção & $\mathrm{P} 4$ & "a paisagem, a paz interior" \\
\hline atenção & P7 & $\begin{array}{l}\text { "a paisagem , a energia assim do lugar (...) o próprio ar (...) fica } \\
\text { deslumbrada com a paisagem ao redor (...) arco-íris foi algo } \\
\text { muito mágico, as cataratas não tem como não se impressionar, } \\
\text { é muito bonito" }\end{array}$ \\
\hline atenção & P16 & $\begin{array}{l}\text { "a paisagem em geral que é fora do que a gente vê todo dia } \\
\text { (...) aqui a potência da natureza é totalmente diferente" }\end{array}$ \\
\hline
\end{tabular}

Fonte: autores. 
Nota-se que os turistas entendem como paisagem aquilo que se pode ver, ou que espera ver, e o que chama a atenção durante o passeio. Pires (2011) afirmou que paisagem é a expressão espacial e visual do ambiente, reunindo e agregando todos seus elementos constitutivos. Neste sentido, percebe-se que o turista compõe essa expressão visual com elementos diferentes.

Como respostas selecionadas no quadro 2 , no contexto temporal motivação, nota-se a composição de um cenário de natureza com vários elementos diferentes, que lhes parece familiar de um parque nacional e que ele imagina ver. Já nos contextos temporais atenção e lembrança, que a paisagem já fez parte de sua experiência, percebe-se que a distinção de elementos ganha consistência. Os participantes observam que a paisagem é formada por elementos distintos, conseguem refazer mentalmente o cenário que viram durante a trilha. Contudo isto não significa que tenham consciência dessa diferenciação.

Quadro 2 - Comentários sobre natureza dos elementos

\begin{tabular}{|c|c|c|}
\hline $\begin{array}{l}\text { contexto } \\
\text { temporal }\end{array}$ & $\begin{array}{l}\text { turista } \\
\text { participante }\end{array}$ & exemplo de comentário (unidade de registro) \\
\hline motivação & P7 & $\begin{array}{l}\text { "vou ver muita natureza, vou ver possivelmente muitos } \\
\text { animais no seu habitat natural (...) as cataratas (...) eu gosto } \\
\text { muito de natureza (...) esse recontato que a gente tem (...) } \\
\text { voltar a se sentir parte da natureza" }\end{array}$ \\
\hline atenção & $\mathrm{P} 1$ & $\begin{array}{l}\text { “a água não é o principal no meu ponto de vista (...) a interação } \\
\text { da natureza, os animais (...) as arvorezinhas (...) algumas } \\
\text { pessoas estão focadas só na água (...) vejo arte no momento, } \\
\text { nos bichinhos ali, nas pessoas parando para tirar aquelas } \\
\text { fotografias, eu achei incrível, uma coisa intensa (...) não é só a } \\
\text { queda, a cachoeira em si, a água, tem uma coisa que envolve } \\
\text { isso que é até mais importante a natureza verde, essas } \\
\text { árvores (...) bem preservado" }\end{array}$ \\
\hline lembrança & $\mathrm{P} 1$ & $\begin{array}{l}\text { "uma coisa constante imaginar essa água aqui quantos anos } \\
\text { está nesta forma e neste lugarzinho (...) uma coisa muito } \\
\text { rica, de árvores escondidas no caminho" }\end{array}$ \\
\hline lembrança & P3 & "as cataratas, a natureza, uma floresta" \\
\hline lembrança & P7 & $\begin{array}{l}\text { "as quedas, um arco-íris, várias árvores e uma multidão de } \\
\text { pessoas tirando fotos" }\end{array}$ \\
\hline lembrança & $\mathrm{P} 12$ & $\begin{array}{l}\text { "essa sequencia das quedas d'água (...) incontável quantas } \\
\text { quedas d'água tem (...) tantos os níveis (...) andorinhas } \\
\text { quebrando aquela barreira atrás da cachoeira" }\end{array}$ \\
\hline
\end{tabular}

Fonte: autores.

A figura 10 apresenta de modo gráfico, os termos dos elementos que fazem parte do conceito de geodiversidade mais expressados pelos turistas durante as entrevistas.

A relação dos termos e das unidades de contextos temporais pode ser vista da seguinte forma: antes da visita, a motivação dos turistas era estar ali pelas: cataratas, principalmente. Sua atenção durante o percurso da trilha foi dividia entre todos os outros elementos. E levaram como lembrança, todos eles, exceto o rio. Cataratas é o termo mais citado na motivação, e na atenção. Na lembrança as cataratas dividem as citações com a água. 
Figura 10 - Termos relativos à geodiversidade em referência temporal

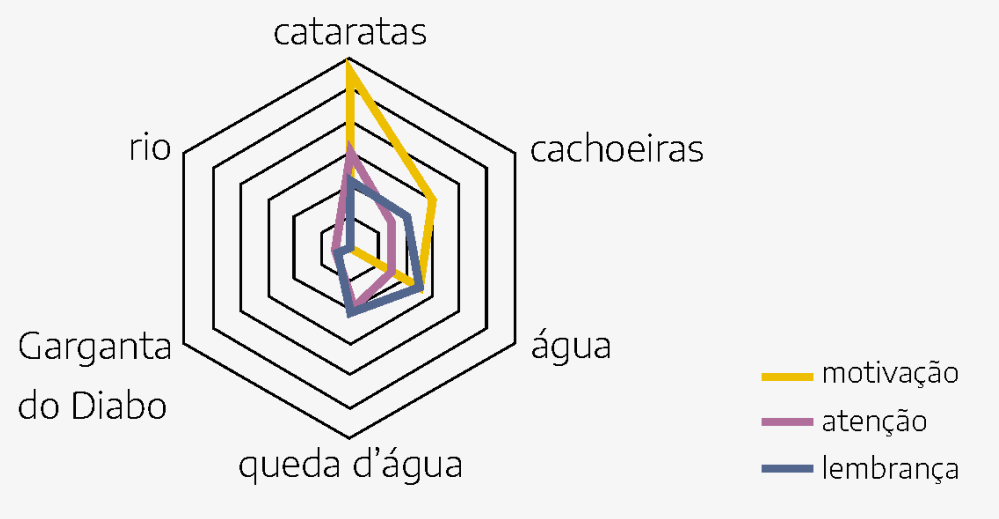

Fonte: autores.

A figura 11 exibe a comparação com termos ditos sobre conteúdos referentes à geodiversidade e também biodiversidade.

Figura 11 - Termos expressados referentes à bio e geodiversidade

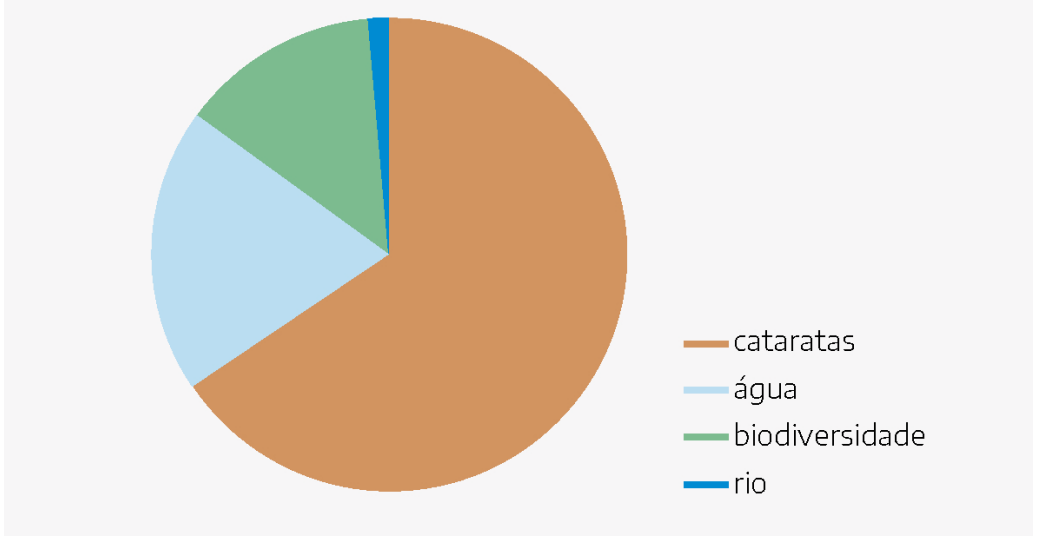

Fonte: autores.

Foram agregados à expressão cataratas e afins os termos cataratas, cachoeiras, queda d'água e Garganta do Diabo que significam o mesmo elemento geomorfológico, e agregados ao vocábulo bióticos os termos como floresta, árvores, andorinhas, animais, entre outros. Na percepção do turista, o rio que é o principal agente formador e transformador daquela paisagem, é quase ignorado.

Informação adicional: são símbolos oficiais da $U^{1}{ }^{1}$ a onça pintada e as cataratas, ao fundo.

A figura 12 apresenta o resultado da análise das informações de todas as categorias das unidades de registro (o que foi dito na entrevista como o comportamento

1. Logomarca oficial PARNA Iguaçu. 
sombreado) para propor a interpretação da experiência turística dos participantes na trilha das Cataratas. Do total de 24 participantes, essa análise foi feita com 22 deles, pois dois não cumpriram o protocolo do método completo. P2 não fez a última parte da entrevista e P11 não fez a observação na trilha.

Figura 12 - Domínios da experiência dos participantes

ENTRETENIMENTO

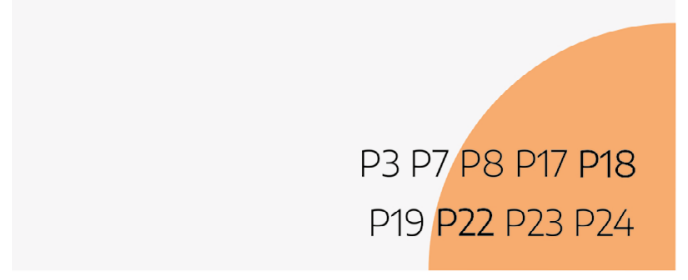

P1 P3 P4 P5 P6 P7 P9 P10 P12

P13 P14 P15 P16 P17 P18 P19

P20 P21 P22 P23 P24

ESTÉTICO
EDUCACIONAL

\section{P18 P20 \\ P21 P22}

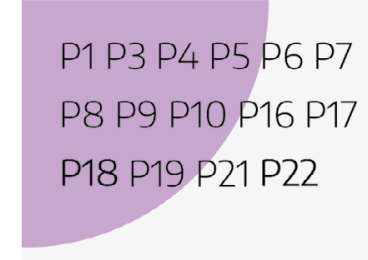

ESCAPISTA

Nota: Participantes da pesquisa inseridos no diagrama baseado em conceitos de Pine II e Gilmore (1998, 1999, 2011).

Fonte: autores.

A análise de quais experiências viveu durante o tempo em que participou da pesquisa foi feita de forma individual. Obviamente, cada participante pode experimentar mais de um domínio, em sua experiência integral.

Cabe observar que apenas P18 e P22 teriam tido uma experiência memorável, porque conseguiram sentir experiências em todos os domínios. 0 exemplo de P18 é bastante interessante. Sua motivação inicial se dá, essencialmente, pelo domínio educacional. Entretanto durante o percurso da trilha o que lhe chamou mais a atenção foram, predominantemente, experiências do domínio estético como unidade de registro (entrevista) e domínio entretenimento, constatada na unidade de registro (Shadowing). 0 turista terminou o passeio e foi classificado na unidade de contexto temporal lembrança como experiência de domínio educacional na entrevista, porém percebeu-se que constituiu escapismo, pois teve participação ativa de imersão, não de absorção. 0 que mais chamou atenção durante a pesquisa, neste caso, foi que na motivação existiu o domínio educacional legítimo e consciente, mas que por falta de meios, ele não prosseguiu como um domínio da experiência.

O turista P22 fez análises sobre sentimento de pertencimento da comunidade local em relação ao parque, além de usufruir das experiências de domínio estético, escapismo e entretenimento, por exemplo, quando conseguiu perceber que a trilha dá uma gradação de emoção, ele diz "o caminho é bastante longo, mas acaba nem percebendo porque tem novidade a cada momento". P20 e P21 também tiveram experiências mais completas. Seus comentários observados no Shadowing continham interesses de informações históricas, sobre os rios da região, poluição das águas e sobre a mata, por exemplo. 
Entretanto, de forma geral, os participantes tiveram mais experiências dos domínios estético e escapismo. Inclusive na questão sobre a geodiversidade.

Para a análise da percepção da geodiversidade na experiência turística excluiu-se a unidade de contexto motivação, pois nela o turista ainda não tinha se aproximado do local ideal - a trilha das Cataratas. Esses dados são a somatória dos domínios da experiência por unidade de contexto temporal (atenção e lembrança) e não por participante. Eles apresentam a junção da experiência turística e quais termos de elementos da geodiversidade foram ditos.

Na figura 13, que apresenta a relação entre referências à geodiversidade e a experiência turística, percebe-se a predominância do domínio estético, onde existe a intersecção da dimensão de imersão física e da participação passiva, ou seja, sem interferência direta sua na própria experiência.

Figura 13 - Geodiversidade e experiência turística (contexto temporal atenção, durante a trilha)

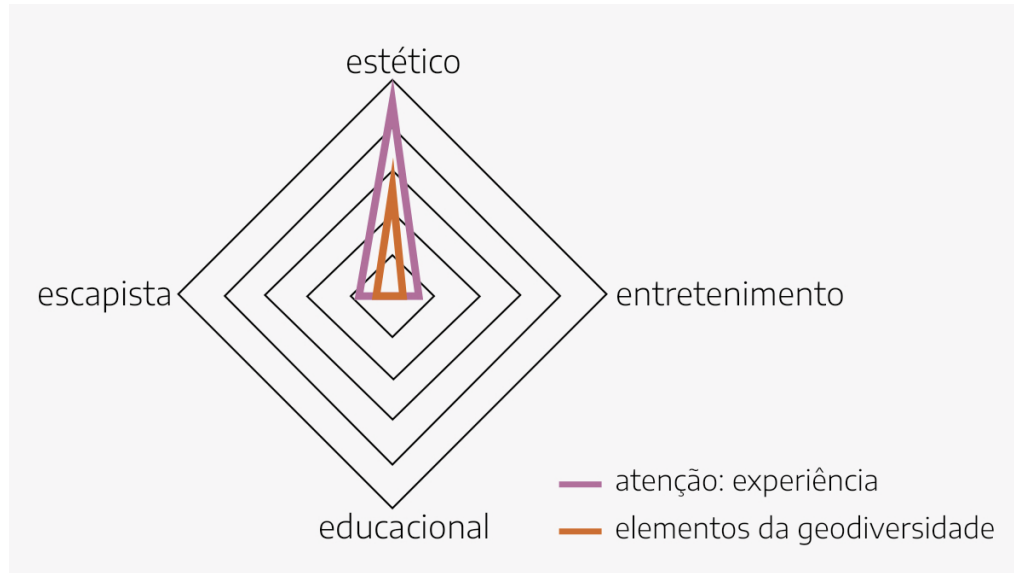

Fonte: autores.

Na comparação entre a experiência e os elementos da geodiversidade, na unidade de contexto temporal lembrança (figura 14), existe uma mudança de comportamento quanto à participação do turista, nesse momento de guardar uma lembrança do lugar. Percebeu-se que o turista volta a estar ativo na composição da sua experiência de memória. Esse registro da experiência na memória pode tornar o turista mais ativo do que na vivência passiva, do contexto temporal imediatamente anterior (atenção). Conforme Larsen (2007), o turista ativa sua participação para registrar sua experiência como memória.

Entretanto, para que o objetivo da pesquisa fosse realmente cumprido e pudesse responder se existe o geoturismo, fixou-se uma lente de aumento da compreensão do elemento de geodiversidade como representante de eventos geológicos, processos geomorfológicos e hidrológicos que aquele local expõe.

Quando o turista P24 disse que "tinha vontade de conhecer as cataratas" o termo catarata, pode significar para ele um elemento de natureza abiótica ou simplesmente a repetição do verbete usado na construção da imagem turística do atrativo.

Por conseguinte, a pesquisa buscou ir além dos termos que se referem aos elementos da geodiversidade e procurou o entendimento do conceito de geodiversidade. Porque se considerou que existe uma diferença entre ver e reconhecer na paisagem uma cachoeira, assim como entre ver e reconhecer a cachoeira 
como geodiversidade. Este "além do que se pode ver" é o reconhecimento do processo de formação, dos elementos geológicos, geomorfológicos, hidrológicos, de solo como: tipos de rochas, os degraus, o relevo, a 'terra roxa', o basalto, o curso do rio etc.

Figura 14 - Geodiversidade e experiência turística

(contexto temporal lembrança, após trilha)

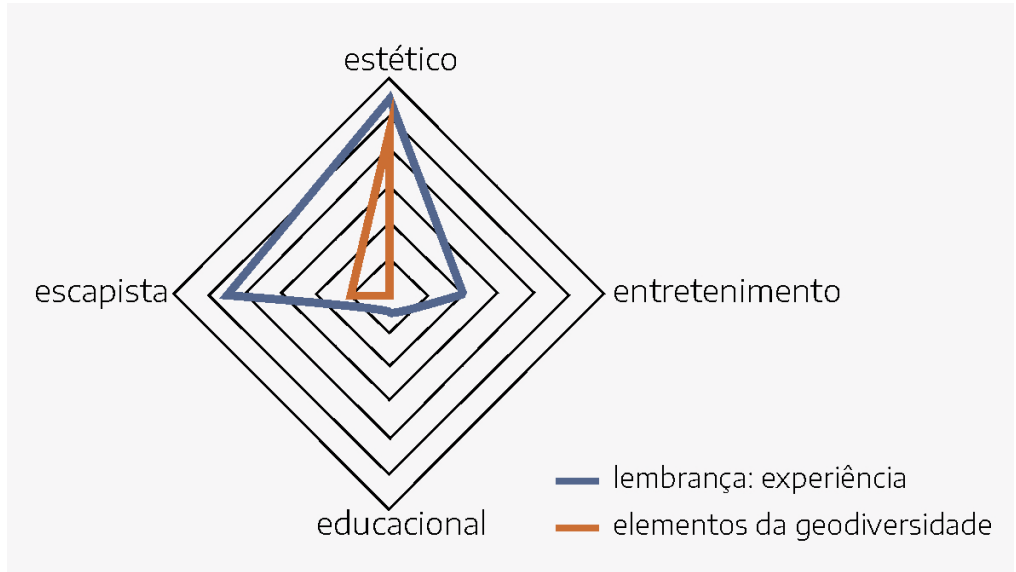

Fonte: autores.

No quadro 3, destaca-se duas respostas à pergunta de qual imagem ficará como lembrança do passeio. Que revelam a composição do cenário mais detalhado, com um passado além do que se vê aqui e agora no presente. E com detalhes da paisagem abiótica, demonstrando que se vê um contínuo interligado, além dos saltos mais famosos. Indicam que o turista tem condições de compreender o processo de formação deles.

Quadro 3 - Aproximação do conceito de geodiversidade

\begin{tabular}{|l|l|l|}
$\begin{array}{l}\text { contexto } \\
\text { temporal }\end{array}$ & $\begin{array}{l}\text { turista } \\
\text { participante }\end{array}$ & $\begin{array}{l}\text { exemplo de comentário (unidade de registro) } \\
\text { "uma coisa constante imaginar essa água aqui quantos anos }\end{array}$ \\
\hline lembrança & P1 & $\begin{array}{l}\text { está nesta forma e neste lugarzinho (...) uma coisa muito } \\
\text { rica, de árvores escondidas no caminho" }\end{array}$ \\
\hline "essa sequencia das quedas dágua (...) incontável quantas \\
\hline lembrança & P12 & $\begin{array}{l}\text { quedas dágua tem (...) tantos os níveis (...) andorinhas } \\
\text { quebrando aquela barreira atrás da cachoeira" }\end{array}$ \\
\hline
\end{tabular}

Fonte: autores.

A primeira frase foi classificada como do domínio estético e escapismo. Nela interpreta-se a percepção de processos físicos, geomorfológicos, assim como das características hidrológicas na composição da paisagem ao se imaginar o tempo da água percorrendo as rochas atuando no desenvolvimento da paisagem das cataratas, o processo modelador do relevo/da paisagem. 0 enquadramento no domínio estético é justificado por ter havido plena contemplação visual das cataratas. A segunda frase encontrada, classificada como do domínio estético, denotou a percepção da estrutura das rochas e sua relação com o relevo pelo turista quando ele vê, contempla visualmente, a sequência das quedas, em níveis de 
rochas. P12 durante o Shadowing revelou também que conhecia um pouco sobre os basaltos da região.

A análise dos resultados indicou que a geodiversidade, como conceito, esteve presente na experiência turística. Entretanto não se pode afirmar que houve consciência dessa aproximação conceitual pelos turistas.

Sem consciência a experiência deixa de ser ativa e volta-se ao domínio puramente estético. Sobretudo porque não existem os intérpretes que auxiliam na promoção das experiências ótimas (Costa, 2009).

E efetivamente, não se pode afirmar que exista hoje uma experiência de geodiversidade dos turistas, bem como geoturismo, em população tão grande como os milhões de visitantes anuais do PARNA Iguaçu (figura 15).

Ao ignorar a dimensão do tempo geológico e os processos de formação do relevo, as pessoas tendem a ver e pensar que as cataratas são hoje como sempre foram. Não percebem os processos criadores e modificadores daquela paisagem, que integram a geodiversidade. Esta constitui a diferença fundamental entre quem vê a paisagem cataratas e quem "vê" com o conceito de geodiversidade. E também constitui a diferença entre quem busca um atrativo turístico e quem busca um atrativo geológico.

Figura 15 - Geodiversidade na experiência turística

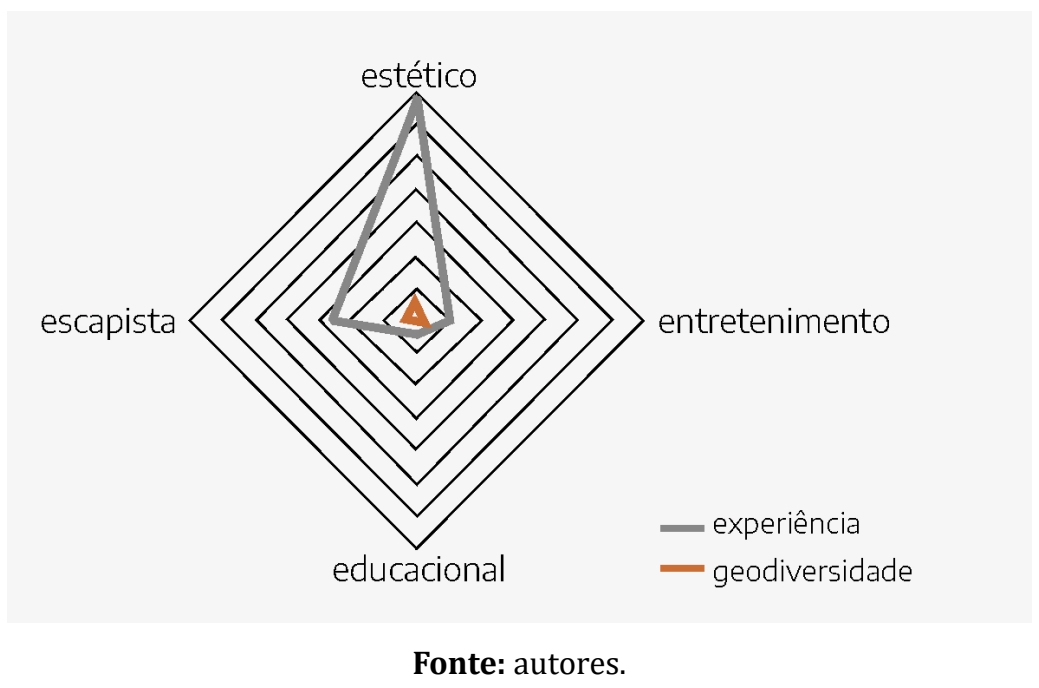

\section{Conclusões}

Nota-se que no modelo pine-gilmoriano a composição de duas dimensões define intervalos de experiências. Nenhuma experiência é plena e estática, ela passa gradualmente para outras, como os ângulos num diedro retângulo, na representação gráfica. Entre duas dimensões de experiências existe uma gradação contínua de estados intermediários, híbridos entre os valores extremos. Ou seja, compostos por características combinadas de ambos, por exemplo, no intervalo do entretenimento ser mais passivo que absorto ou vice-versa. Afinal trata-se da inesgotável experiência humana. Apesar dessa complexidade, as pesquisas em turismo têm se utilizado do modelo pine-gilmoriano com êxito, obtendo análises de comportamento do turista em relação as mais variadas atividades. Justamente 
porque o modelo dá a oportunidade de um turismólogo fazer uma análise comportamental de um sujeito social.

A observação como sombra, por meio do método Shadowing, somando-se a capacidade de classificação das sensações do modelo pine-gilmoriano, foram determinantes para a compreensão sobre se a geodiversidade fez parte da experiência vivida pelo turista no cenário das Cataratas.

A análise de 22 participações completas indicou que os turistas chegaram ao parque com motivação predominantemente estética e alguns, do domínio escapismo. Neste último caso, manifestado pela sua expectativa de "entrar" em outro universo, o da natureza, que lhe é precioso e distante do seu cotidiano.

Durante o percurso da trilha, a contemplação foi máxima. Sua atenção quase totalmente voltada ao contato visual, ao longo da trilha, lhe dá a percepção de que a paisagem que vê é formada por muitos elementos, um cenário maior que as cataratas.

Somente quando o turista refletiu sobre o que viveu ali, e preparou sua memória para guardar aquela experiência, é que se percebem somar mais solidamente os domínios escapismo e entretenimento. 0 turista ativou sua participação para formar suas memórias e se sentiu absorto de contentamento.

Embora tenham sido encontrados distintos conteúdos sobre composição da paisagem nos comentários dos 24 participantes, a pesquisa expôs a falta de compreensão dos turistas sobre a diferenciação dos elementos bióticos e abióticos, inclusive sobre sua consequente interdependência.

Apesar da quantidade de registros de palavras consideradas elementos abióticos nas entrevistas, não se identificou percepção do que sejam elementos de geodiversidade. Desta forma, se não há entendimento do conceito, conforme revelou a pesquisa, considerou-se que tais palavras poderiam ter sido pronunciadas em repetição à imagem turística construída pelo produto turístico e mídia.

Se o turista não compreende o conceito de geodiversidade, o turismo está então trabalhando com as paisagens naturais e não com os elementos que a formam. Por não entender sobre a evolução geológica/geomorfológica do cenário o turista se apega às experiências profundas do visual e do sentimental. E repete o que lhe é mais familiar entre os elementos que compõem a paisagem.

Considerando-se o entendimento do conceito, não existe geodiversidade no parque para os turistas. Também não existem meios interpretativos disponíveis para o turista se informar sobre detalhes da paisagem e, portanto não existe o geoturismo como experiência desta visita. A prática de geoturismo só pode acontecer se o turista tiver a consciência do conceito de geodiversidade.

Essa consciência pode ser oferecida por meio da interpretação, contribuindo para a divulgação das Geociências, como mais um conteúdo a ser trabalhado também pelo turismo. Portanto, considera-se que o geoturismo deva ser entendido como atividades com objetivo de interpretação do ambiente abiótico que possam ser incorporadas a quaisquer outras atividades turísticas, de modo a ampliar a experiência, agregando o domínio educacional, com participação ativa e consciente na absorção, bem como contribuindo para a formação cidadã e agregando valores comerciais e econômicos à localidade visitada.

Os meios interpretativos, acrescidos do conteúdo da geodiversidade, estimularão a experiência educacional com algo novo sobre aquele lugar que o atraiu. Essa mediação de conteúdos viabilizaria uma experiência mais completa, para aqueles que desejarem. 
Pine II e Gilmore (2011) afirmaram que sempre se deve facilitar experiências completas, ricas e memoráveis às pessoas. Entregar conhecimento científico a turistas que viajam motivados apenas por experiências estéticas ou de entretenimento não prejudicam seu prazer e fruição, apura-os.

0 turista pode preferir aprender algo mais passivamente, sendo entretido em uma visita guiada. Ou aprender algo tocando. Ou de forma mais evasiva e ativa com meios que o ajude a interagir com a paisagem. Ou contemplar a paisagem nos mirantes comparando com placas interpretativas que indiquem a relação da estrutura das cataratas, camadas de basalto etc. Para alguns turistas o produto geodiversidade será o principal, para outros, periférico; e para outros ainda, complementar. Todos esses turistas estarão na mesma trilha, e ao mesmo tempo. Por esta razão, ao dar condições e motivá-los a acessar e receber informações, a experiência certamente será enriquecida.

\section{REFERÊNCIAS}

Beni, M.C. (2002) Análise estrutural do turismo (7a ed.). São Paulo, Brasil: Editora SENAC.

Bezerra, L.T. (2019). Experiência Memorável de Turistas em Natal-RN. Revista Turismo em Análise, 30(3), 480-495. https://doi.org/10.11606/issn.1984-4867.v30i3p480-495

Brasil (2011). SNUC Sistema Nacional de Unidades de Conservação da Natureza: Lei no 9.985, de 18 de julho de 2000; Decreto no 4.340, de 22 de agosto de 2002; Decreto no 5.746, de 5 de abril de 2006. Plano Estratégico Nacional de Áreas Protegidas: Decreto no 5.758, de 13 de abril de 2006. Ministério do Meio Ambiente, 76 p. https://antigo.mma.gov. $\mathrm{br} /$ legislacao/areas-protegidas

Brilha, J. (2005). Património Geológico e Geoconservação: a conservação da natureza na sua vertente geológica. Viseu, Portugal: Palimage Editores.

Boven, L.V. \& Gilovich, T. (2003). To Do or to Have? That Is the Question. Joumal of Personality and Social Psychology, 85(6), 1193-1202. https://doi.org/10.1037/ 0022-3514.85.6.1193

Carcavilla, L. (2012). Geoconservación: un recorrido por lugares geológicos excepcionales para entender cómo y por qué debemos protegerlos. Madrid, España: Instituto Geológico y Minero de España/Catarata.

Carter, T.J. \& Gilovich, T. (2010). The The relative relativity of material and experiential purchases. Journal of Personality and Social Psychology, 98(1), 146-159. https://doi.org/ $10.1037 / \mathrm{a} 0017145$

Cataratas do Iguaçu S.A. (2021). Mapa turístico do Parque Nacional do Iguaçu. https:// cataratasdoiguacu.com.br/mapas/

Cohen, E. (1979). A phenomenology of tourist experience, Sociology, 13(2), 179-201. https://doi.org/10.1177/003803857901300203

Conti, E., Forlani, F. \& Pencarelli, T. (2020). Visiting a cultural city in the experiential perspective: the case of Urbino. Il capitale cultural: Studies on the Value of Cultural Heritage, 21, 391-424. http://dx.doi.org/10.13138/2039-2362/2117

Costa, F. R. (2009). Turismo e patrimônio cultural: interpretação e qualificação. São Paulo, Brasil: Editora Senac São Paulo.

Creswell, J. (2010). Seleção de um projeto de pesquisa. In: J. Creswell, Projeto de pesquisa: métodos qualitativo, quantitativo e misto (Tradução Magda Lopes, 3ํㅡㄹ., 25-47). Porto Alegre, Brasil: Artmed. 
Csikszentmihalyi, M. (1990). Flow: The Psychology of Optimal Experience. New York: Harper Collins, $303 \mathrm{p}$.

Cutler, S.Q. \& Carmichael, B.A. (2010). The Dimensions of the Tourist Experience. In: M. Morgan, P. Lugosi, \& J. R. B. Ritchie (Eds.), The Tourism and Leisure Experience: consumer and managerial perspectives (3-26). Bristol: Channel View Publications.

Gândara, J.M.G. (2018,julho). Comunicação oral apresentada em banca de defesa de mestrado de Rapanelli, R.V. (2018) no programa de pós-graduação em Turismo da Universidade Federal do Paraná, Curitiba, Brasil.

Gândara, J.M.G.; Fraiz Brea, J.A. \& Manosso, F.C. (2013). Calidad de la experiência em los hoteles termales de Galicia, España: un análisis a través de la reputación online. Estudios y Perspectivas en Turismo, 22, 492-525. https://www.estudiosenturismo. com.ar/PDF/V22/N03/v22n3a07.doc.pdf

Gray, M. (2013). Geodiversity: valuing and conserving abiotic nature (2 ${ }^{\underline{a}}$ ed.). Oxford, United Kingdom: John Wiley \& Sons.

Hose, T.A. (2012). 3G's for modern geotourism. Geoheritage, 4, 7-24. https://doi.org/ 10.1007/s12371-011-0052-y

Houshold, I. \& Sharples, C. (2008). Geodiversity in the wilderness: a brief history of geoconservation in Tasmania. Geological Society, 300, 257-272. doi:10.1144/SP300.20

IBAMA - Instituto Brasileiro do Meio Ambiente e dos Recursos Naturais Renováveis. (2002). Plano de Manejo do Parque Nacional do Iguaçu. Brasília, Brasil: Ministério do Meio Ambiente.

ICMBio - Instituto Chico Mendes de Conservação da Biodiversidade (2018). Plano de Manejo do Parque Nacional do Iguaçu. https://www.icmbio.gov.br/portal/images/ stories/plano-de-manejo/plano_de_manejo_do_parna_do_iguacu_fevereiro_2018.pdf

Jennings, G. (2006). Perspectives on quality tourism experiences: An introduction. In: G. Jennings \& N.P. Nickerson (Eds.) Quality Tourism Experiences (1-22). Oxford, United Kingdom: Elsevier Butterworth-Heinemann.

Kolody, H. (1995). Cataratas Do Iguaçu. Viagem no espelho (2 ${ }^{\underline{a}}$ ed.). Curitiba, Brasil: Editora da UFPR.

Larsen, S. (2007). Aspects of a Psychology of the Tourist Experience. Scandinavian Journal of Hospitality and Tourism, 7(1), 7-18. https://doi.org/10.1080/15022250701226014

Licht, O.A.B. \& Arioli, E. E. (2020). A photographic atlas of the architecture, flow geometry and morphology, and fácies of the Serra Geral Group (Paraná Igneous Province) in the state of Paraná, Brazil. Boletim Paranaense de Geociências 76(1), 1-69. DOI:10.5380/geo.v76i0

Maack, R. (1968). Geografia Física do Estado do Paraná. Curitiba, Brasil: Papelaria Max Roesner Ltda.

Marujo, N. (2016). Turismo, turistas e experiências: abordagens teóricas. Revista Turydes: Turismo y Desarollo, 20. http://hdl.handle.net/10174/20116

McDonald, S. (2005). Studying actions in context: a qualitative shadowing method for organizational research. Qualitative Research, 5(4), 455-473. https://doi.org/ $10.1177 / 1468794105056923$

McDonald, S. \& Simpson, B. (2014). Shadowing research in organizations: The methodological debates. Qualitative Research in Organizations and Management, 9(1), 3-20. https:// doi.org/10.1108/QROM-02-2014-1204

Mehmetoglu, M. \& Engen, M. (2011) Pine and Gilmore's Concept of Experience Economy and Its Dimensions: An Empirical Examination in Tourism. Journal of Quality Assurance in Hospitality \& Tourism, 12(4), 237-255. https://doi.org/ 10.1080/1528008X.2011.541847 
Minayo, M.C.S. (2017). Amostragem e saturação em pesquisa qualitativa: consensos e controvérsias. Revista Pesquisa Qualitativa, 5(7), 1-12. https://editora.sepq.org.br/ $\mathrm{rpq} /$ article/view/82/59

Oh, H.; Fiore, A.M. \& Jeoung, M. (2007). Measuring Experience Economy Concepts: Tourism Applications. Journal of Travel Research, 46(2), 119-132. https://doi.org/ $10.1177 / 0047287507304039$

Pezzi, E. \& Vianna, S.L.G. (2015). A Experiência Turística e o Turismo de Experiência: um estudo sobre as dimensões da experiência memorável. Revista Turismo em Análise, 26(1), 165-187. https://doi.org/10.11606/issn.1984-4867.v26i1p165-187

Pine II, B.J. \& Gilmore, J.H. (1998). Welcome to the experience economy. Harvard Business Review, 76(4), 97-105. https://hbr.org/1998/07/welcome-to-the-experience-economy

Pine II, B.J. \& Gilmore, J.H. (1999). The Experience Economy - Work is Theatre and Every Business a Stage. Boston, Massachusetts, United States of America: Harvard Business School Press.

Pine II, B.J. \& Gilmore, J.H. (2000). La economia de la experiência: El trabajo es teatro y cada empresa um escenario. Buenos Aires, Argentina: Ediciones Granica S.A.

Pine II, B.J. \& Gilmore, J.H. (2011). The Experience Economy (Update edition). Boston, Massachusetts, United States of America: Harvard Business Review Press.

Pires, P.S. (2011). Marco teórico-metodológico de los estudios del paisaje. Perspectivas de aplicación en la planificación del turismo. Estudios y Perspectivas en Turismo, 20(3), 522-541. https://www.estudiosenturismo.com.ar/PDF/V20/N03/v20n3a01.pdf

Rapanelli, R.V. (2018). A geodiversidade na experiência dos turistas do Parque Nacional do Iguaçu - PR, Brasil. [Dissertação de mestrado]. Universidade Federal do Paraná. https://acervodigital.ufpr.br/handle/1884/58063

Rapanelli, R.V.\& Feger, J.E. (2018). Geodiversidad y turismo en las investigaciones académicas. Estudios y Perspectivas en Turismo, 27(3), 647-665. https://www.estudiosenturismo. com.ar/PDF/V27/N03/v27n3a09.pdf

Salamuni, R.; Salamuni, E.; Rocha, L. A. \& Rocha, A. L. (2002) Parque Nacional do Iguaçu, PR - Cataratas de fama mundial. In: Schobbenhaus, C.; Campos, D. A.; Queiroz, E. T.; Winge, M.; \& Berbert-Born, M. L. C. (Ed.) Sítios Geológicos e Paleontológicos do Brasil. DNPM/CPRM - Comissão Brasileira de Sítios Geológicos e Paleobiológicos (SIGEP) Brasília. 1, 313-321. http://sigep.cprm.gov.br/sitio011/sitio011.htm

Serrano, E. \& Ruiz, P. (2007). Geodiversidad: concepto, evaluación y aplicación territorial. El caso de Tiermes Caracena (Soria). Boletín de la A. G.E., 45, 79-98. https://bage.agegeografia.es/ojs/index.php/bage/article/view/640

Stamboulis, Y. \& Skayannis, P. (2003). Innovation strategies and technology for experiencebased tourism. Tourism Management, 24, 35-43. https://doi.org/10.1016/S0261-5177 (02)00047-X

Trevisan, F. L. (2020). A visitação turística no Parque Nacional do Iguaçu. Boletim Goiano de Geografia, 40,1-24. https://doi.org/10.5216/bgg.v40i01.62736

Trigo, L.G.G. (2010). A viagem como experiência significativa. In: Trigo, L.G.G. Turismo de Experiência (21-42). São Paulo, Brasil: Editora SENAC.

Unesco - Organização das Nações Unidas para a Educação, a Ciência e a Cultura. (2020). Sítios do Patrimônio Mundial Natural no Brasil. https://pt.unesco.org/fieldoffice/ brasilia/expertise/natural-world-heritage.

Urry, J. (2001). O Olhar do Turista: lazer e viagens nas sociedades contemporâneas 3. ed. São Paulo, Brasil: Studio Nobel e SESC. 


\section{AGRADECIMENTOS}

Ao Instituto Chico Mendes de Conservação da Biodiversidade (ICMBiO) E Ao Parque Nacional do IguAÇu. À EMPRESA CATARATAS do IgUAÇU S.A. Ao Polo IgUASSU - InSTITUTO PARA DESENVOLVIMENTO DA REgião trinacional. Ao Grupo de PESQuisa CNPQ/UFPR - GeoconserVaÇão E Patrimônio Geológico. À geóloga Kimberlym Vieira, PElo aChado do REtrato poÉtico das Cataratas por Helena Kolody.

\section{CONTRIBUIÇÕES}

Raquel Virginia Rapanelli: definição do problema de pesquisa e objetivos; desenvolvimento da proposição teórica; realização da revisão bibliográfica e fundamentação teórica; escolha dos procedimentos metodológicos; coleta e análise das informações; elaboração de tabelas, gráficos e figuras; redação, revisão crítica e adequação do manuscrito às normas da RTA.

José Elmar Feger: revisão crítica do manuscrito.

Luiz Alberto Fernandes: apoio na pesquisa de campo, discussão e revisão da geodiversidade, e revisão crítica do manuscrito. 